\title{
GLOBAL PANDEMIC IN TERMS OF OBJECTIVE CAUSES AND SUBJECTIVE SPECULATIONS
}

\author{
Alexander N. Chumakov \\ Lomonosov Moscow State University, Russia \\ Pavel S. Yurchenko \\ Lomonosov Moscow State University, Russia
}

\begin{abstract}
The coronavirus pandemic has generated a lot of talk about the postcoronavirus future of the global community and has drawn close attention to the processes of globalization. The article notes that something similar in the public consciousness took place after the publication of the first report to the Club of Rome, when there quickly came the awareness of the danger posed by global problems. Now, one of the global problems - the coronavirus pandemic - has changed the usual rhythm of life of the entire world community in a matter of weeks. The relevance of the topic is urgent since even those who used to show no interest both in the problems of medicine and global problems, now have actively joined the discussion. As a result, on the pages of many printed and electronic publications, along with serious and verified information, all sorts of guesses and speculations about the nature and correlation of coronavirus and globalization are multiplied. According to the authors, only knowledge can be opposed to this.
\end{abstract}

Keywords: coronavirus pandemic, globalization, epidemic, global problems, knowledge, world community.

\section{History Lessons}

In the second half of the twentieth century, when the contradictions in the interaction between nature and society sharply escalated and reached the global level, the wellknown scientists and public figures, concerned with global problems, created an international public organization - the Club of Rome - to investigate the fundamentally new threats to the humanity and attract wide public attention to them. But the first attempts to pass such challenges showed that neither the diverse scientific community, nor broad segments of population understood the real state of affairs and the looming threat for the humanity. At the same time, nothing could make people look at the rapidly changing world and at people themselves in this world from a different perspective. And most of all, the members of the Club of Rome, who visited various countries and continents, were saddened by the people's indifference manifested in their attitude to their own fate. Almost all layers of the population, from ordinary citizens to representatives of various levels of government, did not see and realize and, most importantly, were reluctant to realize the growing danger.

Journal of Globalization Studies, Vol. 12 No. 2, November 2021 157-168

DOI: $10.30884 / j o g s / 2021.02 .08$ 
Recalling that time, the founder and first President of the Club of Rome, Aurelio Peccei, wrote

As if the global problems that we were trying to draw everyone's attention to were not related to our planet at all, but to some very different, distant planet... Our words found no more response than the preaching of Pope, the exhortations of UN Secretary-General U Thant, or, say, the warnings of concerned scientists and thinkers. It seemed that they were forgotten even before they were heard (Peccei 1980: 99).

The only needed thing was an event that would resemble a shock treatment. Something completely unusual that could cause the effect of 'Out of the blue' and make people see the impending dangers and think about human fate. This task was then successfully completed by a group of scientists led by Dennis Meadows, who prepared the first report to the Club of Rome called 'Limits of growth'. Its publication in 1972 was the turning point after which it became almost impossible to ignore global issues.

And now, half a century later, a similar situation has developed, but in new conditions and in a different format. Even the world community, where, as before, 'no one, in fact, bears or even feels responsible for the state of the whole world' (Peccei 1980: 111), experienced a literal shock which, however, was caused not by the publication of the next report of concerned scientists, but by the natural course of events. In other words, nature has delivered a harsher and more instructive lesson to the world community in the form of the coronavirus epidemic, which in a matter of weeks gripped the whole planet and figuratively issued an ultimatum to the world community.

One could hardly imagine what happened a few months ago. People's everyday lives changed suddenly and dramatically. People, cities, and even countries went into self-isolation mode and found themselves virtually locked within their borders. Planes stopped flying, transport flows sharply decreased, and the breakdown of technological chains and economic ties led to a wave of bankruptcies and to the shutdown of many businesses around the world. The entertainment, tourism, and sports industries have ceased to function. Hotels, cinemas, restaurants, stadiums and other public gathering places became empty. Personal contacts were reduced to a minimum and replaced by online communication. Many types of jobs, production, business and other meetings, leisure, education, conferences, etc. were held online. The scale and speed of the changes turned a real shock and a complete surprise even for the scientific community.

Against this background, there was a lot of serious and idle talk about the nature and causes of the coronavirus. In addition, all these talks are mostly associated with globalization, its role and significance in the current situation. And this is quite understandable. We are forced to turn to the topic of globalization due to the dramatically changed circumstances. Even those, who yesterday did not hesitate to use the Internet and modern means of communication, bought in stores domestic and industrial goods produced in various countries, and fruits and vegetables grown in the most exotic corners of the planet, suddenly realized that all this, in the end, closes on the whole globe, on the whole planet and is something interconnected, interdependent, as a whole. Henry Farrell and Abraham Newman correctly noted in this regard that

Globalization involves further specialization of labor between countries, this model increases efficiency incredibly, but at the same time leads to unprecedented vulnerability. Strikes like the COVID-19 pandemic reveal a similar 
vulnerability. A single supplier or region that specializes in a single product can cause the entire system to become fragile during a crisis, and the entire supply chain can be disrupted. In the coming months, we will see even more manifestations of this vulnerability (Farrell and Newman 2020).

While agreeing with this assessment of the impact of globalization on the economy, one should emphasize that a human being is the key element of this global system. Thus, no matter how anyone previously treated global processes or the same level of problems, structures, movements, and whatever ideas they had about them, one can hardly ignore the connection between coronavirus and globalization. But the judgments and resulting assessments deserve special attention.

\section{From Coronavirus to Globalization}

So, the global scale of the spread of coronavirus and its consequences has sharply turned the public interest and attention towards global issues. Against this background, many publications have appeared where authors, regardless of their qualifications and professional affiliation, are so actively seeking to speak out about globalization and its connection with the coronavirus that all this strongly resembles the times of the formation of ancient Greek philosophy. At that time, called 'natural philosophy', the main attention of the thinkers was focused on reflecting over the nature and essence of the universe, and every self-respecting philosopher considered it his duty to write a work entitled 'About nature'. So now the media space is literally flooded with publications that, along with the topic of coronavirus, certainly talk about globalization.

The pages of various publications are full of relevant headings of articles where we are talking about the downward trend of global processes, or even about the 'end' of globalization, which is defined as a 'vestige and atavism' (Yevstafyev 2020). Terms such as 'deglobalization' and 'anti-globalization' have emerged and are increasingly being used. The corresponding terminology is becoming more widespread in popular speculation about the 'sunset', 'end', 'collapse', 'stop', and 'death' of globalization. Here are just some headlines of this kind: 'Did the coronavirus kill globalization?', 'Globalization died because of the coronavirus', 'Will the coronavirus stop globalization?', 'The end of globalization: how will the coronavirus change the world economy', 'Can anti-globalization begin after the coronavirus?', 'Will the coronavirus bury the era of globalization?', 'On the impact of the COVID-19 pandemic on the processes of globalization' and etc.

It is quite obvious that the coronavirus as a litmus test has shown an extremely wide range of opinions about what is globalization. At the same time, there is a clear trend when judgments about this extremely complex phenomenon are made without reference to special knowledge and authoritative sources, from the position of 'this is what it seems to me'. Another analogy comes to mind: the times when people looked at the sky and, due to evidence at the level of common sense, concluded that 'the Sun revolves around the Earth', 'the stars light up and go out', the Moon 'radiates light', 'goes behind the clouds' and etc. A typical example of such judgments is the subjective opinion of the author of one of publications who writes that 'The sense of crisis in the world of globalization was formed in 2019 for too many people to be just self-deception. The system of globalization, which seemed quite stable, collapsed quickly, almost instantly (the curtailment of international trade and global air travel occurred in just a month) and from a relatively small push' (Yevstafyev 2020). A similar speculation about the 'interruption' 
of globalization is found in publication of another author, who states, '...Here's what's particularly interesting. It turned out that globalization can be paused - close borders and cancel air traffic, impose strict restrictions on movement within countries' (Ivanchenko 2020). Another statement from many others of the same kind belongs to the German political scientist Helfried Munkler: 'The COVID-19 pandemic that has hit the world will put an end to the euphoria of globalization' (The Humankind Feels... 2020).

And even those who, on the whole, adequately perceive modern globalization can draw wrong conclusions from this. For example, Mikhail Khanov, on the one hand, correctly notes, 'Let's not forget that the process of globalization goes far beyond the purely economic integration of individual countries. This is only its most visible practical level. At a deeper level, there is a rivalry of cultures, ideologies, and political influence'. And at the same time, speaking about Japan he says that it 'will suffer more than many other countries from the temporary trend towards deglobalization (emphasis added. - A. Ch., P. Yu.)' (Khanov 2020). Vladimir Pryakhin makes the same mistake when he says that 'globalization is an objective process. It can be slowed down (emphasis added. $-A$. Ch., $P$. Yu .) by specific conjuncture circumstances, but it cannot be "canceled"' (Pryakhin 2020: 1473-1480).

Such simplistic ideas about globalization, its trends and development prospects can be explained by the fact that this is a rather complex phenomenon, whose essence can only be revealed as a result of a comprehensive interdisciplinary analysis. In addition, most people tend to trust their feelings and first impressions when they first deal with something plausible and consistent with their common sense. So the above-mentioned authors and publications easily judge globalization, without bothering to get acquainted with the special literature on Globalistics, or at least with the relevant reference publications (Mazur and Chumakov 2003; Chumakov, Mazour, and Gay 2014; Anheier and Juergensmeyer 2012; Chumakov 2020), not to mention a serious dive into the essence of this phenomenon. As a result, their judgments about globalization are, at best, superficial, fragmentary, since the attention in this approach initially focuses on what first attracts attention and for those who do not have special knowledge seems quite obvious. As a rule, it concerns the confrontation and clash of interests in the global world, certain negative consequences of human activity, or, for example, the success of some and the lack of results of others. At the same time, responsibility for such problems in the modern world is usually assigned to the loosely interpreted globalization and those who allegedly initiated it, and now 'manage' it in their own interests.

Hence, there are many 'theories' and judgments about different types, models, projects, and variants of globalization. At the same time, it is called liberal, oligarchic, or capitalist... A sample of the judgment in line with this paradigm is the excerpt from Dmitry Yevstafyev's article where he writes,

It is hardly surprising that the concept of globalization - which in the American version, in European interpretation of the American version, in the Chinese amendments to the American version did not include any real geoeconomic multipolarity, high 'delegation' of military-police powers to individual allies within the previously formed within a American-centric (and no other) model of global development of macro-regions (Yevstafyev 2020).

The basis of such judgments is still the same - an uncritically borrowed or purely personal view of globalization from their point of view, when the subjective factors of 
global processes are exaggerated, or even completely absolutized, while their objective prerequisites and natural history remain without due attention. But even if they recognize the primacy of objective factors in relation to subjective ones, they often go to the other extreme when they talk about globalization. For example, only from an economic or political point of view, while ignoring other areas of public life. This is usually the fault of narrow specialists who do not go beyond their subject and professional horizons. A typical example of this approach is the position of the above-cited American scientists Farrell and Newman, who, in particular, write,

Globalization has created a complex system of interdependence. Companies happily built global supply chains, and as a result, intricate production networks connected the entire global economy... Production has become global, and at the same time the interdependence of countries has increased, since no country can fully control all the goods and components needed by its economy. National economies have become participants in the global supply chain (Farrell and Newman 2020).

In general, everything is correct here, except that globalization has not 'created a complex system of interdependence,' but has opened up opportunities for such interdependence (Stychinskiy 2019). And this is not the same thing (the system of interdependence is created by people). But the important thing is that the authors speak only about one sphere of public life in the context of globalization - the economy, whereas we are now dealing with a multi-aspect globalization, which in addition to the economy, covers almost all other spheres of public life: political, social, cultural, scientific, educational, sports, information, environmental, etc. (Sukhina 2018). Why is it so important to take these clarifications into account? Well, at least because Marcus Aurelius also said, 'Your life is what You think it is.' In other words, our ability to act appropriately is directly proportional to the adequacy of our understanding of the reality around us.

Regarding politicians, public figures, journalists, or the 'opinion of the people', it is even easier - they usually talk about these topics to the best of their competence 'on duty' or simply because it is relevant. We should also note that serious scientists from a wide range of professional backgrounds are also involved in such conversations. And that is quite understandable. No one has a monopoly on discussing globalization. It is only important to clarify - if they are scientists, in what field? For example, if a wellknown biologist or climate scientist begins to seriously discuss a liberal or some other model of globalization, then very soon the question will arise about his professional affiliation and the level of his competence in the field of Globalistics. And in the part that concerns not natural science but social disciplines. It is quite obvious that the 'scientific value' of such conversations will not be worth the time spent on them.

Unfortunately, it is precisely this kind of unprofessionalism that we often encounter when we hear or read about some kind of model or globalization initiated and managed by someone. There is no need to give additional arguments and evidence of the failure of such judgments, since many serious works have already been published on this subject, which are quite accessible both in the open press and on the Internet (Globalistika 2016; Chumakov 2019; Beck 2000). Let us just note that there are no fundamental disagreements in the academic community regarding the fact that, in its most general form, globalization is a natural-historical process of universalization and formation of structures, connections and relations in various spheres of public life that are common to the entire planet Earth. 
Thus, being an objective historical phenomenon (and a process), globalization itself cannot be evaluated positively or negatively, as well as, for example, scientific and technological progress. Of course, it is associated with both positive and negative results of human activity in an environment where the world is increasingly becoming a complete closed system. And, of course, people have a certain influence on certain aspects of global processes when, for example, they take appropriate steps in the field of demography, ecology, poverty reduction, or health care. But this does not mean that globalization as a whole can be stopped, reversed, or managed at will. It is irreversible and has its own logic of development. In other words, since after the Great geographical discoveries, the humankind has more and more become a global phenomenon (in the literal sense of the word), it is no longer possible to reformat the growing global processes into regional or local ones, just as it is impossible, for example, to reverse the growth of a person and return him to childhood.

\section{Epidemics and Pandemics - Companions of the Humanity}

But there remains a legitimate question about the connection between the coronavirus pandemic and globalization. Is there such a connection and, if it exists, what is its nature and how has it appeared? The question is quite logical, since many things indicate this. But, as noted above, not everything that seems obvious is of such a nature in reality. So it is not easy to understand the relationship between coronavirus and globalization.

Let us start with the fact that globalization creates, initiates and exacerbates various problems of the planetary scale. They are called global because they fit the well-defined criteria of globality and relate to various spheres of public life of the world community (Mazour, Chumakov 2006: 228-232). This allows us to classify such problems into groups; one of them includes the healthcare problems (Globalistika 2006: 408-409). So, coronavirus, being one of the many diseases that people suffer from, became an integral part of the overall global healthcare problem, when this disease very quickly overcame the threshold of an epidemic, gained a global scale and became a pandemic. Here it is important to clarify the two key concepts of 'epidemic' and 'pandemic'.

An epidemic is an outbreak of an infectious disease that covers at least 5 per cent of the population of a particular country or a single population. Epidemics are a constant and permanent companion of the humankind. A pandemic is defined as a disease outbreak that acquires a massive character, affecting a significant part of the population of several neighboring countries, and even more countries of the world. With the expansion of humanity to the regional and then global level, epidemics became able to evolve into regional and global pandemics. There were quite a few cases of this kind in world history, and the current coronavirus is only one of the varieties of pandemics. Below we will talk about the features and conditionality of the modern scourge of globalization, but now we will look at the varieties and dynamics of only some of these diseases that took many thousands and even millions of human lives.

So, archaeological excavations give reason to talk about cases of epidemics in ancient times. In particular, about five thousand years ago, a mysterious disease desolated an entire region in the north-east of China; here archaeologists found several places where houses were preserved but stuffed with skeletons. There is also information about a prehistoric epidemic that broke out around $3000 \mathrm{BC}$. History has preserved more complete and reliable records about a series of outbreaks of such infamous epidemics as smallpox, cholera, plague, typhoid, diphtheria, measles, influenza, and AIDS. 
As for smallpox and cholera, for example, they have been known since ancient times as highly contagious infections, with a mortality rate of more than 40 per cent. The first smallpox epidemics, according to the chronicles, were recorded in Asia in the period from the fourth to the eighth century, when the population of China and Korea decreased by a quarter, and Japan - by more than a third. In the seventeenth and eighteenth centuries, smallpox was rampant in Europe and Russia, killing up to 1.5 million people a year. But even greater troubles were brought by recurring large-scale outbreaks of the plague (the Plague of Athens - the fifth century BC; the Antonine Plague - the second century; the Plague of Justinian - the sixth century; the Black Death - the fourteenth century; the plague pandemic of 1894, which originated in China and India and then spread to port towns) (McNeill 1976).

Another example of the same nature is the flu pandemics, which also periodically haunt humanity. The most massive and deadly one broke out in 1918. It became known as the 'Spanish flu' and is estimated to have killed between 70 and 100 million people. At that time, it was about 5 per cent of the world's population; in addition, another half a billion people were infected. This pandemic was the first time in the humankind's history when the healthcare problem went beyond not only local, but also regional borders and reached the global level.

Does this mean that all previous pandemics were not global? Yes, that is exactly the case. The fact is that until the era of fundamental globalization, which began at the turn of the nineteenth-twentieth centuries (Mazour, Chumakov 2006: 963-965), healthcare problems in general, and various pandemics, in particular, did not go beyond regional scales. Until the end of the nineteenth century, relatively insignificant contacts and a small speed of movement of large masses of people over long distances were the limiting factors for the spread of any diseases, including infections. In other words, moderate migration of the population, as well as spatially limited military campaigns and battles, was an important factor in localizing epidemics and pandemics within certain local or regional territories.

However, the situation has changed fundamentally with the onset of fundamental globalization which at the turn of the nineteenth-twentieth centuries made the basic spheres of public life - economy and politics - become a fully global phenomenon. The economic ties, political contacts, and relations finally took a global outlines and increased mobility. Scientific and technological progress, which gave people trains, steamships, and then cars and planes, enormously expanded the ability to move and communicate directly with vast number of people on a global scale and in real time. The First World War and the associated active movement of large masses of people, as well as the military clashes between numerous armies, also contributed to a rapid spread of another infection that emerged at that time - the Spanish flu. As a result, the virus spread at such an unprecedented rate that in the first 30 weeks of its existence, more than 35 million people died worldwide. In total, from 1918 to 1919, the Spanish flu affected about 550 million people, which was almost one-third (29.5 per cent) of the world's population at that time. Thus, we may say that since that time healthcare, as another problem that has never lost its relevance, but prior to the twentieth century it was necessarily geographically limited, has become one of the global problems of our time.

\section{Features of the Modern Pandemic}

Returning to the COVID-19 pandemic, it is important to emphasize that its outbreak occurred during the period of multi-dimensional globalization that began in the second 
half of the twentieth century (Globalistika 2016: 568-572). A distinctive feature of this stage of development of globalization is the fact that now hardly any sphere of public life that is not directly or implicitly involved in global processes. This explains the extraordinary and in many ways shocking situation with the coronavirus, as well as the unusual and rather harsh reaction of the authorities at all levels around the world.

If we compare the current pandemic with the Spanish flu, we should note that the former unfolds in the significantly different circumstances. Suffice to say that over the last one hundred years separating these two events, the world population has grown from 1.85 to 7.75 billion people, in other words, it has increased more than fourfold! At the same time, railways and highways covered almost the entire land surface of the planet with a dense web; fast ships of all types and sizes are plowing almost all water spaces: rivers, lakes, seas and oceans. And in place of the first military airplanes of the early twentieth century, numerous modern civil airliners have come, moving millions of passengers to all corners of the planet in a matter of hours.

One may also conduct a thought experiment to show the scale of the changes that occurred between the first and second global pandemics. So, if you mentally go back a hundred years and imagine looking at our planet from the window of a spaceship, you would see only dark space there. And now, if you look at modern night photos of the Earth taken from space, its continents are absolutely clearly visible. Almost all the land on the planet, with the exception of deserts and mountain ranges, is covered with bright lights. Add to this the myriad hordes of tourists and vacationers, politicians and businessmen who were essentially non-existent a century ago, and who are constantly moving around the world. And also - international conferences, congresses, forums, championships and sports competitions, exhibitions, fairs, tours, etc. From this point of view, the incredible speed of the spread of the coronavirus from China to Italy, the United States, Russia, South Africa or Brazil, as well as the unprecedented response to the pandemic by authorities around the world, become quite understandable. Of course, the adoption of such drastic and decisive measures was also influenced by the genetic memory left by the disaster experienced a century ago.

But what has not changed is that, as before, every country is left alone in the face of global danger. And even in the seemingly tightly integrated European Union, the situation appeared no better. As Sunil Venaik rightly points out in this regard,

In the face of coronavirus' global sweep, most national governments acted independently from each other, rather than in unison. Just as in global action on climate change, the responses of nations to the health crisis have largely been ad hoc, piecemeal and, in many cases, lethally ineffective (Venaik 2020).

\section{Lessons and Conclusions}

First of all, we need to understand and take into account the fact that we live in a multiaspectual globalization, which we can neither cancel nor redirect in any rational direction. The manifestations and nature of global processes in society, for example, in healthcare or environmental protection, to a certain extent depend on the relevant policies and behavior of people, but this fact does in no way guarantee that in the future the humankind will no longer face such challenges. Moreover, it is a matter of time. And it does not come down to the fact that the next epidemic will certainly break out natural way. Even now, there are many reasons to speak about the artificial nature of the cur- 
rent coronavirus. So, not only in Wuhan but also in many other similar centers of the world, there are laboratories where medical, biological, chemical and other experiments are conducted. In addition, the level of their secrecy can only be guessed. And who can guarantee that there will not be created biological or chemical weapons that will not intentionally or accidentally get out of control? In this connection it is noteworthy presenting an authoritative opinion of the head of the National medical chamber of the Russian Federation Dr. Leonid Roshal, who in an interview to Forbes said about a new coronavirus infection, 'When I analyze the current situation, I understand that this is a rehearsal before a biological warfare' (TASS 2020).

Is the threat from many other global problems caused or conditioned by globalization getting smaller every day?! Unfortunately, it is not. Already in the $1980 \mathrm{~s}$, foreign and national scientists convincingly proved that the accumulated nuclear charges in the world are enough to completely destroy the whole world community. In particular, the concept of 'nuclear winter' is just a warning. But the perception of its urgency has since waned, while the threat of using nuclear weapons has only increased. In addition, one can hardly ignore other weapons of mass destruction. However, the list of potential shocks to the world community does not end here. So, according to many authoritative experts, in the coming decades the planet will face a global crisis caused by climate change. This topic is increasingly becoming the subject of public attention, which is eloquently indicated, in particular, by the statement of Microsoft founder Bill Gates, who wrote in his blog, 'As terrible as the pandemic is, climate change could be even worse' (Gates 2020).

Thus, the main lesson that follows from the current situation is that both individual countries and humanity as a whole need to take the modern global world seriously and with knowledge, while adequately assessing their far-reaching opportunities to change it at will and discretion.

Another conclusion is that the Great geographical discoveries that gave rise to a new historical era - the era of global events, connections and relationships - just laid the foundation for global processes in society, which now in such quality (as global phenomena) will always accompany humankind as long as it retains the status of a planetary phenomenon. Hence, when we talk about the coronavirus pandemic, it is important to keep in mind that our conversation is not about some of the numerous global processes in general, (taking into account the processes in the geosphere and biosphere) but those that occur in society and relate to healthcare. But, as modern Globalistics shows, all global processes and related problems are closely interrelated. The aggravation of one of these problems directly or implicitly exacerbates the others.

It follows that when facing the coronavirus pandemic, the humanity must realize not only the immense danger posed by this disease, but also threats coming from many other equally serious and very real dangers. At the same time, the world community is figuratively walking on the edge of a precipice; yet, it has not crossed the dangerous line. And the best thing to do in this situation is not to lose optimism and search for acceptable solutions. And the coronavirus outbreak just makes us use a new angle on ourselves and the global world in which we live in.

In this regard, the question arises as to whether the coronavirus will affect globalization, and how the world order will change after the epidemic. We think that the coronavirus will hardly have a direct impact on globalization because of various global problems. If problems are not generated by global processes, then they are caused by 
them. And the coronavirus pandemic, as noted above, is only one of the humanity's global problems. However, this pandemic will undoubtedly affect the behavior and relationships of people, as well as the economy and other spheres of public life, and to some extent the global world order. We can already see the growing social, economic and political tension in society. And it is not only in individual countries, but also in the world community in general.

It is quite obvious that the national borders closure and the almost complete interruption of international transport links for such a long time, as well as the shutdown of many industries, the growing unemployment, a significant decline in the standard of living of the absolute majority of population, restrictions on civil rights, etc. will lead to even more serious than today consequences not only within individual countries, but also at the international level. An example of such quite noticeable changes caused by the coronavirus is the differences, grievances and claims of individual countries within the European Union regarding the interaction and mutual assistance in overcoming the pandemic. A similar example is the transformation of the trade war between the United States and China into a set of more complicated contradictions, where the pandemic undoubtedly plays the role of a catalyst. This is also pointed out by American researchers, noting that

while the administration of Donald Trump is using the pandemic to reject global integration, the People's Republic of China is trying to demonstrate its readiness to take the lead in a crisis. China was the first to be hit by the new coronavirus and has indeed been seriously affected in the past three months. But now he is beginning to recover, while the rest of the world is gripped by the disease (Farrell and Newman 2020).

There are many other aspects of public life that have been seriously affected by quarantine measures and self-isolation. So, the increased need for digital technologies caused by the pandemic and the strengthening supervision over the citizens' health on this basis is fraught with quite serious danger. It is critical to draw a clear distinction between the benefits of digitalization and the threat of emerging 'digital Big Brother' that restricts fundamental human rights and freedoms. The economic efficiency that digitalization brings cannot be bought at the price of 'digital totalitarianism' (Medvedev 2020). There is no doubt that education, conducting scientific events or viewing museum exhibits in the online format after overcoming the pandemic, will undoubtedly be actively used and thus change, among other things, the configuration of international relations.

We may continue the list of possible changes caused by the coronavirus but one thing is certain - only time will show the full depth and specific details of the upcoming changes absolutely accurately and impartially (Grinin 2019: 3-24). What we can and should do is to get ready for such changes. They will hardly proceed in a smooth manner. But we must not complicate the existing situation. In the present situation which is full of uncertainty, the main thing is not to make abrupt and unreasoned steps at all levels but to search for joint solutions and make compromises. Our planet has become too 'small' for more than 7.5 billion of its inhabitants and, as events, similar to the latest social unrest in the United States show, one thoughtless action can cause a chain reaction of large-scale destructive consequences. In other words, we are talking about a policy of pragmatism, a policy of 'small steps' towards living together on our common 
planet. In today's interdependent global world, such a strategy and tactic of behavior is clearly preferable to any quick and radical decisions or the desire for 'survival alone'.

\section{Funding}

The research was carried out with the financial support of the Russian Foundation for Basic Researches (RFBR) in the framework of the research project No. 19-511-93002 ('Cultural and philosophical foundations of Sino-Russian cooperation').

\section{REFERENCES}

Anheier, H. K., and Juergensmeyer, M. (eds.) 2012. Encyclopedia of Global Studies. California: SAGE Publications, Inc.

Beck, U. 2000. What Is Globalization? Malden, MA: Polity Press.

Carpenter, S., Enfu, C., Milanovich, B., Munkler H., de Montbrial, Th.,, and Vodolazkin, E. 2020. The Humankind Feels the Urgent Necessity to Close the Door. Expert opinion survey. Global Affairs, May 13. URL: https://globalaffairs.ru/articles/zakryt-dveri/. Original in Russian (Водолазкин, Е., Карпентер, С., Миланович, Б., Мюнклер, Г., Тьерри де Монбриаль, Эньфу Ч. «Человечество почувствовало настоятельную необходимость закрыть двери». Опрос экспертов разных стран. Россия в глобальной политике).

Chumakov, A. N. 2020. Philosophy of Globalization. Selected articles. $3^{\text {rd }}$ ed. Moscow: Moscow University Press.

Chumakov, A. N. 2019. Global World: The Clash of Interests. Moscow: Prospekt. Original in Russian (Чумаков А. Н. Глобальный мир: Столкновение интересов. М.: Проспект).

Chumakov, A. N., Mazour, I. I., and Gay, W. C. (eds.) 2014. Global Studies Encyclopedic Dictionary. With a Foreword by Mikhail Gorbachev. Amsterdam/New York, NY: Editions Rodopi.

Evstafyev, D. 2020. Coronavirus Pandemic: The Way There, but not Back. Expert, April 6. URL: https://expert.ru/expert/2020/15/pandemiya-koronavirusa-put-tuda-no-ne-obratno/. Original in Russian (Евстафьев, Д. Пандемия коронавируса: путь туда, но не обратно. Эксперт).

Farrell, H., and Newman, A. 2020. Will the Coronavirus End Globalization as We Know It? Foreign Affairs, March 16. URL: https://www.foreignaffairs.com/articles/2020-0316/will-coronavirus-end-globalization-we-know-it.

Gates, B. 2020. COVID-19 is Awful. Climate Change could be Worse. GatesNotes, March 4. URL: https://www.gatesnotes.com/Energy/Climate-and-COVID-19.

Grinin, L. 2019. Looking into the Future: Forecasts for the $21^{\text {st }}$ Century. Vek Globaliztsii 3: 3-24. Original in Russian (Гринин Л. Е. Взгляд в будущее: прогнозы на XXI столетие. Век глобализации 3: 3-24. DOI: 10.30884/vglob/2019.03.01).

Ilyin, I. V., Mazur, I. I., Chumakov A. N. (eds.). 2016. Global Studies Directory: People, Organizations, Publications. Moscow: Knorus. Original in Russian (Глобалистика. Персоналии, организации, труды. Энииклопедический справочник / Гл. ред.: составители И. В. Ильин, И. И. Мазур, А. Н. Чумаков. 2-е изд., стер. М. : Кнорус).

Ivancheno, V. 2020. Coronavirus: Fear is not the Best Adviser. Global Affairs, March 17. URL: https:/globalaffairs.ru/articles/koronavirus-strah-ne-luchshij-sovetchik/. Original in Russian (Иванченко В. Коронавирус: страх - не лучший советчик». Россия в глобальной политике, 17 марта). 
Khanov, M. 2020. Will the Coronavirus Bury the Era of Globalization? TASS, June 2. URL: https://tass.ru/opinions/8626299. Origin in Russian (Ханов М. Похоронит ли коронавирус эпоху глобализации? TACC, 2 июня).

McNeill, W. H. 1976. Plagues and Peoples. Knopf Doubleday Publishing Group.

Mazour, I. I., and Chumakov A. N. (eds.) 2003. Globalistics. Encyclopedia. Moscow: Raduga. Original in Russian (Мазур И. И., Чумаков А. Н. Глобалистика. Энциклопедия. М.: Издательство «Радуга»).

Mazour, I. I., Chumakov A. N. (eds.) 2006. Global Studies: International Interdisciplinary Encyclopedic Dictionary. St. Petersburg: Elima, Piter. Original in Russian (Глобалистика: Международный междисииплинарный энциклопедический словарь / Гл. ред.: И. И. Мазур, А. Н. Чумаков. М. - СПб. - Н.-Й. : ИЦ «ЕЛИМА», ИД «Питер»).

Medvedev, D. 2020. Security Cooperation during the new Coronavirus Pandemic. Global Affairs, July-August. URL: https:/globalaffairs.ru/articles/bezopasnost-v-period-pandemii/. Original in Russian (Медведев Д. Сотрудничество в сфере безопасности в период пандемии нового коронавируса. Россия в глобальной политике).

Peccei, A. 1980. The Human Quality. Moscow: Progress. Original in Russian (Печчеи А. Человеческие качества. М.: Прогресс).

Pryakhin, V. F. 2020. About the Impact of the COVID-19 Pandemic on the Processes of Globalization. Voprosy politologhii 10 (5): 1473-1480. Original in Russian (Пряхин В. Ф. О воздействии пандемии COVID-19 на процессы глобализации. Bonpocы политологии. Т. 10. № 5 (57). C. 1473-1480).

Stychinskiy, M. S. 2019. Cultural and Philosophical Analysis of the Processes of Cultural Genesis in the Context of Glocalization. Russian Humanitarian Journal 8 (5): 313-321. Original in Russian (Стычинский М. С. Культурно-философский анализ процессов культурогенеза в условиях глокализации. Российский гуманитарный журнал 8 (5): 313-321).

Sukhina, I. G. 2018. Mass Culture as a Globalizing Phenomenon. Russian Humanitarian Journal 4: 206-272. Original in Russian (Сухина И. Г. Массовая культура как глобализационный феномен. Российский гуманитарный журнал 4: 206-272).

TASS - Roshal Called the Pandemic a 'Biological Warfare Rehearsal'. 2020. TASS, August 3. URL: https://tass.ru/obschestvo/9106435. Origin in Russian (Рошаль назвал пандемию "репетицией биологической войны". ТАСC)

Venaik, S. 2020. Coronavirus hasn't Killed Globalisation - it Proves why we Need it. The Conversation. URL: https://theconversation.com/coronavirus-hasnt-killed-globalisationit-proves-why-we-need-it-135077. 